Taking Stock: Assessing and Improving Performance Budgeting Theory and Practice

\author{
Forthcoming in \\ Public Performance and Management Review \\ 38(3), pp. 1-34
}

$\begin{array}{ccc}\text { Elaine Yi Lu, Ph.D } & \text { Zachary Mohr, Ph.D. } & \text { Alfred Tat-Kei Ho, Ph.D. } \\ \text { Associate Professor } & \text { Assistant Professor } & \text { Associate Professor } \\ \text { Department of Public } & \text { Department of Political } & \text { School of Public Affairs and } \\ \text { Management } & \text { Science and Public } & \text { Administration } \\ \text { John Jay College of Criminal } & \text { Administration } & \text { Wescoe 4060 } \\ \text { Justice } & \text { University of North } & \text { University of Kansas } \\ \text { The City University of New } & \text { Carolina Charlotte } & \text { Lawrence, Kansas 66049 } \\ \text { York } & \text { 9201 University City } & \text { Email: alfredho@ku.edu } \\ \text { 445 West 59th Street, RM } & \text { Blvd, Charlotte, NC } & \text { Phone: (785) 864-3416 } \\ \text { 3534N } & \text { 28223 } & \text { Fax: (785) 864-5208 } \\ \text { New York, NY 10019 } & \text { Email: zmohr@uncc.edu } & \\ \text { Email: ylu@jjay.cuny.edu } & \text { Phone: (704) 687-7438 } & \\ \text { Phone: 631-867-6118 } & \text { Fax: (704) 687-1400 } & \\ \text { Fax: 212-237-8919 } & \end{array}$

The authors would like to thank the insightful comments of the anonymous reviewers of this article. They are very helpful. 


\begin{abstract}
Since the passing of the Government Performance and Results Act (GPRA) of 1993, the past 20 years represent one of the most remarkable eras for performance budgeting initiatives in the United States. As a result, many studies about this tool have also been conducted and published. Based on a systematic review of articles on performance budgeting-related research in major journals in the ten years between 2002 and 2011, this study assesses how performance budgeting research has evolved over time, reviews its accomplishments, and suggests a few directions for future studies, such as the need to control for different intervening factors to establish causality, the need for more coherent theoretical frameworks to guide empirical work and structure the relationship between causal factors, and the need for methodological diversity. We also present a few long-standing questions of performance budgeting that future studies may revisit carefully.
\end{abstract}

Keywords: performance budget, performance based budget, performance management, PBB, GPRA, PART 


\section{Taking Stock: Assessing and Improving Performance Budgeting Theory and Practice}

\section{Introduction}

2013 was the $20^{\text {th }}$ year since the passing of the Government Performance and Results Act (GPRA) of 1993. These 20 years represent one of the most remarkable eras for performance initiatives in the United States. From performance reporting exercises under the GPRA framework, to the Performance Assessment Rating Tool proposed by the Bush administration, to the Obama administration's focus on performance evidence-based decision-making, the U.S. federal government has continued to experiment with different tools and mechanisms to integrate performance measurement and reporting with budgeting. At the same time, $32(80 \%)$ of the 40 states that have passed performance budgeting-related legislation have done so within the past 20 years (Lu \& Willoughby, 2012). Many local governments have also introduced different performance budgeting systems (Melkers \& Willoughby, 2005; Poister \& Streib, 1999). Although these reforms have enjoyed varying degrees of success, performance budgeting movement is pervasive.

As a result of this boom in performance budgeting practices in the U.S., many academic studies about this tool have also been conducted and published during the past ten years. From descriptive analyses of different practices and mechanisms, to evaluative studies about the impact of reforms, to normative and critical studies about the values and pitfalls of different models, scholars have contributed significantly to the volume of academic studies in this area. The use of performance information, however, is still deemed both half-empty and half-full (Kamensky, 2012). Is this because we have hit "the limits of any formal government-wide performance requirements" (Moynihan \& Lavertu, 2012, p. 601)? Or is it because we have not 
found the proper approach(es), if any, to incorporate performance information in decision making, especially in a context as political as budgeting?

Based on a systematic review of articles on performance budgeting in 14 major journals in the ten years between 2002 and 2011, this study attempts to assess how performance budgeting research has evolved over time. Public policy and public administration has a history of conducting systematic reviews of important literature to make the knowledge more relevant to researchers as well as to practitioners who must use the research (O’Toole, 1986; Lindblom, 1979). In this paper, we try to address these questions: What are the impacts of performance budgeting? What factors influence the success of performance budgeting? What research methodologies are commonly used? Finally, what are the key theoretical models and foundations of the past studies?

Assessing the past is important for setting the stage for the future. In particular, given the new context of governance in the $21^{\text {st }}$ century, such as rising fiscal stress faced by many governments, concerns over long-term liabilities and social inequity, are there new research questions that future performance budgeting research should focus on in the coming years? What new methodologies should future researchers consider? What other theoretical frameworks should future studies explore more? Using these questions as our framework of analysis, this study takes stock of what we know, and then provides a roadmap for future studies to help advance the practice and understanding of performance budgeting.

\section{Assessment Methodology}

While there is no universally accepted definition of performance budgeting, the term is generally used to refer to the practice of integrating performance measurement information into 
the budgetary process so that managers can manage public resources more effectively and efficiently and policymakers can use the information to hold agencies accountable for results. There are many possible systems and models in this integration process. Based on performance budgeting practices among developed economies, the Organization for Economic Co-operation and Development (OECD) categorizes performance budgeting into three types: presentational performance budgeting, which simply puts performance information into budget documents; performance-informed budgeting, which uses performance information in the budget deliberative process but does not give the information any predefined weight in the decisions; and direct performance budgeting, which allocates resources based on results achieved (Curristine, 2005; OECD, 2007).

Because of these diverse practices and the lack of consensus among scholars on the formal definition of performance budgeting, we do not exclude any practices or models of "performance budgeting" when we review past research findings. Instead, we accept the judgment of the authors when they define the practice as "performance budgeting" or when they describe the practice as a formal way to integrate performance information into the budgetary process. Because of resource constraints and our desire to have a systematic and consistent methodology in selecting review subjects, we do not include any books or working papers. The scope of our review is therefore limited to 12 Social Science Citation-Indexed (SSCI) journals and two prominent but non-SSCI journals in the field of public budgeting and finance ${ }^{1}$. We first used keyword searches of the titles and abstracts of journal articles using these terms, "performance"” (wildcard) and "budget*" (wildcard), together. We also used the terms "pbb" and "performance assessment rating" to catch potentially related articles. The authors then read through the abstracts, and if necessary, the content, of the articles to determine if the articles 
focused on the practice and impact of performance budgeting, or practices of budgeting that had to do with performance issues. Studies that were about general budgeting but not related to performance issues were excluded. Likewise, studies that were about performance but not linked to the budgetary process, budgetary documentation, or budgetary outcomes were excluded. We also did not include book reviews and symposia introductions. Based on these criteria, we obtained 61 articles related to performance budgeting that were published between 2002 and 2011 in the selected journals.

The articles were then coded systematically for information relating to research questions, methodology, theoretical frameworks, and primary findings. As others have noted, any attempt to comprehensively examine any burgeoning field of study is necessarily limited most importantly by the researcher's awareness of contributions (O'Toole, 1986). We believe that our systematic review captures a good portion of the literature on this topic but important omissions are inevitable. For example, we do not conduct any review of non-English language materials, even though these studies have expanded significantly for the past decade and offer many interesting insights about the implementation and challenges of performance budgeting reforms in different governance and cultural settings.

\section{The State of the Field}

There are many ways to summarize the state of the field. We start the discussion by presenting the findings on the two most commonly studied aspects of performance budgeting: the impact of the tool and the factors that influence its success. Then we review the methodologies and theoretical frameworks used in these studies and some of the long lasting issues identified by the literature as seemingly inevitable challenges to performance budgeting. 


\section{The Impact of Performance Budgeting}

Typically, a budget process is divided into four stages: executive budget preparation, legislative appropriation, budget execution and program management, and audit. If performance measurement is integrated into budgeting, a natural question is how the tool impacts these four stages of budgeting.

[Table 1 and 2 about here]

Out of the 61 studies reviewed, 27 (44 percent) evaluate the impact of performance budgeting on the executive budget preparation, 31 (51\%) on the legislative appropriation process, $26(43 \%)$ on budget execution and program management, and only $2(3 \%)$ on auditing. Given the legislature's power of the purse, many researchers' interests focus understandably on the legislative phase. However, there has been a growing interest in how performance information is used in other phases of budgeting in recent years, even though this focus has fluctuated over time (see Table 1). In the mid-2000s, more attention was paid to the impact of performance budgeting in the executive preparatory stage. Between 2002 and 2007, when the Bush administration began to implement the Program Assessment Rating Tool (PART), there was growing interest in the role of performance budgeting in budget execution, but interest began to wane in the late 2000s.

Among the 27 studies that examine the impact of performance budgeting on the executive budget preparation process, 81 percent find some impact of performance budgeting, and these impacts are wide-ranging, from changing the presentation of budgetary information, 
modifying the budgetary structure and process, and changing the amount of budget requests, to enhancing the communication among departments and between the executive and legislative branches of the government (Willoughby and Melkers, 2000; U.S. GAO, 2003). For example, at the U.S. federal level, performance information is now fully integrated into agencies' strategic planning and budgetary preparation process (Breul, 2007; Ho, 2007), and performance information seems to have strengthened the focus on program management and results by the budget office and agencies (Posner \& Fantone, 2007). At the state level, Grizzle and Pettijohn (2002) show that the Florida performance budgeting reform led to new operating and reporting guidelines from the Governor's Office and the Office of Planning and Budgeting. It also impacted executive communication with the Office of Program Policy Analysis and Governmental Accountability. Jordan and Hackbart (2005) show that the majority of their state budget survey respondents agreed that performance budgeting was successful or somewhat successful in changing the budget process, and Lu (2011) shows that budget office and agencies were more likely to use performance information if performance budgeting reforms centered more on agencies' needs. At the local level, performance budgeting is more likely to show a significant impact in large cities since these cities are more likely to have incorporated performance measurement into the budgetary process (Ho \& Ni, 2005). For smaller jurisdictions, such as cities with populations fewer than 50,000, performance measurement may not be required and performance information may be rarely used in the budgetary process (Rivenbark \& Kelly, 2006).

While performance budgeting has clearly shown some impact on the structure, process and communication of the executive budget preparation process, only 42 percent of those studies that focus on the impact of performance budgeting on the legislative appropriation process show 
that the tool has an impact on the legislature. About one quarter of the studies show that performance budgeting impacts the structure and communication of the legislative process, only 19 percent show that performance budgeting impacts the power distribution of the process, and only two out of 31 studies (6 percent) show that performance budgeting has some impact on the legislative culture.

Compared with the impact on the legislative stage, the impact of performance budgeting is considerably stronger in the budget execution stage. About 65 percent of the 26 studies that examine the budget execution stage find evidence of some impact. For example, Willoughby (2004) shows that the majority of state budgeters perceive performance budgeting as an effective or somewhat effective tool to improve program management and agency communication internally and externally. At the local level, a survey study by Melkers and Willoughby (2005) and a case study by Ho (2011) show similar findings about the communication and program management effects of performance information. However, for the majority of the rest of the studies, the exact impacts of performance budgeting are not specified clearly. Only less than one-third of the studies find some impact on the budget execution process and structure, such as changing the program structure or operational process, and only 23 percent of the studies suggest that the tool impacts the resource allocation or the communication process. Also, only a few studies (15\%) find that performance budgeting changes the political structure and power distribution. For example, Dull (2006) and Ho (2007) show that performance budgeting can shift more power to the budget office and strengthen the chief executive's political control over agencies. Hence, even though the majority of the studies have found some impacts on budget execution, future studies should explore more specifically what those impacts are. 
Finally, the audit stage of budgeting may be related to performance. However, only two of the 61 journal articles examined in this study have any discussion about the effects of performance budgeting on the audit stage (Lu 2011; Melkers \&Willoughby, 2005), and only one of them finds some impact on the audit stage by showing that performance information may be used to target audits (Melkers \&Willoughby, 2005). The very thin findings here should not be used to infer that performance information is not important to auditing. What we have found here may only indicate that performance auditing is often viewed by public administration scholars as a separate field and that studies focusing on performance audit or how performance information is used in auditing are likely to fall outside of the sampling frame of this study.

In summary, these findings seem to reiterate a story that many past studies have asserted - performance budgeting is more likely to be an executive tool, rather than a legislative appropriation tool. Moreover, performance budgeting may strengthen program management and impact the structure and process of budgeting, such as strengthening the ties between strategic planning, goal setting, and public reporting. The focus on results in executive budgeting may also improve inter-agency and executive-legislative communication. Hence, it is not just about influencing the budget allocation. In fact, only about 20 percent of the studies that analyzed the impact of performance budgeting in different stages of budgeting showed any significant impact on the monetary allocation amount. The few studies that show some budgetary impact tend to concentrate at the state level (Burns \& Lee, 2004; Willoughby, 2004; Reddick, 2007; Klase \& Dougherty, 2008). Hence, the existing literature is quite pessimistic about using performance information to influence the amount of budget requests or legislative appropriations. Long-time observers of performance budgeting even advise against any mechanistic link between performance results and budgetary allocation (Joyce, 2003; Posner \& Fantone, 2007). 


\section{The Factors Influencing the Success of Performance Budgeting}

In addition to performance budgeting impacts, another important and growing line of research focuses on the factors influencing how performance information can be integrated into budgeting successfully. One cautionary note before we present the findings is that due to the frequent use of descriptive methods in the literature, the factors identified by the literature do not necessarily validate causality. In most of the studies examined, no control variables were applied.

With this caveat, we find that there are a total of 27 kinds of factors. Table 3 presents the factors' frequency and percentage identified as important. Overall, the top three factors that are important for the use of performance in budgeting are: "Quality of Measurement" (mentioned by 61 percent of the articles), such as how to define program outcomes, collect measurement data, and select the appropriate performance measures, "Political Support" (51\%) and "Executive Leadership Support” (33\%).

Clearly, with 27 factors identified, the literature review suggests that the field is not short of providing factors that influence the use of performance information in budgeting. However, the coverage of these variables varies considerably (see Table 3). To generalize the results and provide a more holistic understanding of the key patterns of the findings, we group these factors into six categories: measurement system, support for performance, investment and capacity, implementation approaches, (dis)incentives, and characteristics of implementation organizations. In this process, we rely primarily on the frameworks suggested in the study by the National Performance Management Advisory Commission (NPMAC, 2010), Lu et al. (2009) and Yang and Hsieh (2007). The general understanding from these studies is that 1) performance budgeting tasks are sequential, from measurement and reporting to management and improving, and these 
activities need to be integrated with the traditional budget processes (Measurement System, Implementation Approaches and (Dis)Incentives); 2) realignment of resources and capacities for performance is important (Investment And Capacity); 3) support from a diverse body of stakeholders is critical (Support For Performance), and 4) performance budgeting is susceptible to the environment in which it operates (Characteristics Of Implementing Organizations).

[Table 3 about here]

Among the group of factors, the category that gets the greatest attention among researchers is "Measurement System", which is an important precursor to performance budgeting. It is not surprising that measurement issues are ranked first because they embody both technical and political aspects of performance budgeting. As Posner and Fantone (2007, p. 365) explain, "far from removing politics from budgeting, the linkage of performance to budgeting raises the stakes associated with performance goals and measures. As such, the performance analysis marshaled to support budget decisions is potentially more vulnerable to political debate and conflict." This high frequency of measurement issues affirms Joyce's call that "a concern for measuring government performance should simply be a concern for measuring it correctly" (Joyce, 1993, p. 3). It also indicates that measurement problems have remained a challenge despite decades of performance budgeting initiatives at the federal, state, and local levels. Specifically, the literature identifies four major concerns in any measurement system --- the quality of measurement, timeliness of the data, linkage with strategic plans, and linkage with resource allocation. The general understanding is that measurement quality is a necessity; timely data makes performance relevant for decisions; linkage with strategic plans (both with agency 
level plans and with government-wide plans) improves the "vertical" integration of performance with planning, where each performance indicator contributes to a larger plan for the future; and the linkage with resource allocation signals that performance matters. The overwhelming finding is that good performance measurement improves the implementation of performance budgeting. However, a few questions remain unanswered. For example, how may researchers know that a measurement system is of high quality? Besides perception surveys, are there other methodologies and standards researchers may use to evaluate a measurement system? Also, the prior literature has suggested categorizing the quality of measurement into four dimensions: measurement validity and reliability, measure usefulness in decision making, administrative feasibility, and political acceptance of measures (Lu, 2008), but this line of research is rather thin. Further study is needed to assess the quality of measurement in performance budgeting systems. "Support for Performance" is the second most analyzed group of factors among the articles reviewed. As expected, political support is the most important issue (for example, see Hou, Lunsford, Sides, \& Jones, 2011). Since budgeting is political, the politics of performance budgeting has been vividly depicted and appreciated by the literature (ranked 2nd out of 27 factors). For instance, Moynihan (2006) argues that performance information is not used in a simplistic way. As he further points out, ambiguity is inherent in organizational life, and so the potential for rival interpretations of performance information as well as policy advocacy influences the use of performance information in budgeting. According to Moynihan, the extent to which performance information contributes to budgeting depends on "the persuasiveness of the arguments made and the intensity of the interest and preferences of the actors involved" (Moynihan, 2006, p. 159). This review of the past studies shows clearly that the use of performance information is often deemed a political choice where political support both enables 
and limits its very survival as a tool. In addition, the importance of executive leadership squares well with the general knowledge in the field. For example, Behn (2002) mentions that energetic leadership for performance distinguishes " an active strategy" (p. 19) from a passive performance system because leadership support nurtures behavioral changes. Furthermore, the importance of legislative support is gaining attention (Bourdeaux, 2006; Bourdeaux, 2008; Posner \& Fantone, 2007). In particular, Bourdeaux (2008)'s research goes beyond the mentioning of the importance of legislature and examines how performance can be integrated with legislative budget process through policy networks maintained by key committee staff.

Also under the cohort of "support for performance," the review shows that management support matters for performance budgeting. "Management" here means the willingness and capacity of management to budget or manage for performance. The roles of management are broadly defined and reflected in various ways in the literature, such as "managerial flexibility" (Breul, 2007), "managerial accountability for performance" (Newcomer, 2007), or the Obama administration's "performance agenda," which embraces an agency-centered approach (Joyce, 2011). Managerial support, a critical component within the factor group, "support for performance," is particularly important for agencies' use of performance information in budgetary decisions. $\mathrm{Lu}$ (2007) finds that the impact of management support is about three times the impact of measurement quality on the use of performance information by agencies. Moynihan \& Lavertu (2012) also emphasize the importance of managerial involvement. The general consensus is that, as $\mathrm{Lu}(2007, \mathrm{p} .13)$ puts it, "for agencies to use measures for budgetary purposes, whether agencies are managed based on performance is critically important." Also, the importance of management support is often put within the context that the management lacks capacity or flexibility to act based on performance information. For example, Newcomer (2007, 
p. 348) notes that "the gap between managerial accountability for performance and authority to shape performance remains to be addressed in many places in the U.S. federal system."

Compared with the significance of political, legislative, executive, and managerial support, the factor of "staff buy-in" is not frequently cited (only 8\%). This finding is somewhat surprising and seems to confirm that performance budgeting is still deemed more as a top-down reform. In addition, although citizen support has caught increasing attention in the recent literature (such as Bourdeaux, 2008; Ho \& Coates, 2004; Kasymova \& Schachter, 2014; Kim \& Schachter, 2013), the role of citizens in general is rather understudied (13\%). Bourdeaux makes a case for strengthening the study of citizens. Recognizing that engaging legislators in performance budgeting is rather difficult, she suggests that "raising the prominence of performance measures through increased efforts at constituent engagement or outreach" $(2008, \mathrm{p}$. 564) holds the potential to significantly change the incentives that legislators face in their decision making process.

An important advancement in the recent literature is the importance of performance culture and shared responsibilities in performance budgeting. There is no doubt that individual stakeholders' participation is important. The concept of "shared responsibility," however, goes beyond shared participation in and commitment to performance budgeting (Breul, 2007; Jordan \& Hackbart, 2005; Lu, Willoughby, \& Arnett, 2009; Melkers \& Willoughby, 2005). Instead, performance budgeting calls for systemic effort, and needs to anticipate the participation of one actor influencing another. For instance, the active role of agencies in performance budgeting may limit the interest of legislators because "executive staff and agencies are not an especially trusted source of information for legislators" to make budgetary decisions (Bourdeaux, 2008, p. 547). After studying participation patterns among actors, $\mathrm{Lu}(2011, \mathrm{p}$. 98) concludes that 
"agencies need to play an active yet not dominant role in performance measurement to achieve better outcome in the performance integration." In short, more participation by one actor does not necessarily mean better outcomes for the performance system as a whole, and the responsibilities need to be shared by important budgetary actors to sustain performance budgeting in a meaningful way. Overall, although the responsibility for supporting performance is increasingly expected to be shared as a manifestation of performance culture, executive leadership support within the chain of command is the most-cited factor among the articles analyzed.

The surveyed literature also confirms that performance budgeting requires various elements identified in the cohort of investment and capacity: time, resources, staff capacity and information system capacity. Specifically, 25 percent of the articles identify resources, 21 percent identify staff capacity, 21 percent identify information system capacity, and 8 percent identify time investment as important. In addition, the variables in the cohort of (dis)incentives for performance budgeting have not yet been well-studied. This, in part, is due to the rare occurrence of the actual use of incentives in budgeting for performance. We observe that the study of formal performance budgeting requirement (i.e. legislation or executive orders), while not yet frequent in the articles surveyed here, is on the rise. Seventy percent of the articles that mention the importance of legal authority or foundation in performance budgeting appear in the last four years of our study period (2007-2011). Clearly, one factor contributing to increased awareness of the legal foundation in the literature derives from the heightened effort to formalize and institutionalize performance budgeting in the past several decades following GPRA, especially in the 1990s. For instance, at the federal level, Breul (2007) calls GPRA "a foundation for performance budgeting." At the state level, Lu and Willoughby (2012) find that 
40 states have performance-informed budgeting laws, and Lu, Willoughby, and Arnett (2009) believe that "legislating results" signals the legislative intent and structures the implementation of performance budgeting. On the other hand, the literature cautions that legal requirements may induce the production of performance information but not the use of performance information (Moynihan \& Lavertu, 2012). Although the subject has not yet been the focus of extensive study, most of the writings on the legal requirements of performance budgeting so far have found that the legal foundation is not only symbolic but also instrumental in implementing performance budgeting. Specifically, the literature indicates that the positive impact of performance laws on performance budgeting implementation is manifested at a minimum of two levels: the presence of the law and the content of law. Its presence signals the legislative intent in strengthening performance budgeting, providing legal authority (Andrews, 2004), and sustaining performanceoriented practices through the transitions of executive leadership change (Chi, 2008). At the same time, a careful craft of the content of laws helps set the system view of performance budgeting and guide the implementation process (Lu et al., 2009; Lu, 2011). The literature indicates that state leaders in performance budgeting tend to have more comprehensive laws that specify measurement linkages to strategic plans, measurement reporting requirements, measurement design, the process of results evaluation, and shared responsibility among various stakeholders more than their counterparts do (Lu et al., 2009; Lu, 2011).

What factors are less likely to be identified as important to the success of performance budgeting? This literature review seems to point out two groups of factors, "Characteristics of Implementing Organizations" and "Implementation Approaches." The emergence of these factors as less important in the literature suggests two competing hypotheses. First, these factors are indeed not that important. Second, these factors are important, but the literature has not yet 
paid enough attention to these contextual factors and how they may constrain or influence the design and implementation of performance budgeting. In the midst of the politics of performance budgeting, whether or not implementation strategies make a difference is yet to be fully tested. In some cases, strategies are blended, and it is hard to trace the causality of impacts. As the title of one article notes, performance activities sometimes represent "[ $t]$ op-down direction for bottom-up implementation" (Long and Franklin, 2004, p. 309).

Another possible explanation for why some variables are less likely to be identified as important is that there are so many additional contextual factors and as a result, any "one size fits all" strategy is impossible. For example, the contextual factors commonly studied include economic factors (such as economic downturn), organizational factors (such as employee size) and demographic variables (such as population). The studies that have looked at these contextual factors have not come to any consensus. One of these studies notes, "one of the major difficulties in performance budgeting is in distinguishing between program impacts based on physical or socio-economic environmental conditions, and those based on management decisions" (Kasdin, 2010). Furthermore, most studies do not have sufficient macro-contextual data and micro-organizational or individual employee data over time and across different types of programs or organizations to study the roles of the contextual factors appropriately. Hence, additional studies at the agency level or at the program level, such as those by Gilmour and Lewis $(2005 ; 2006)$ and Ho (2011), are needed in the field.

Overall, the literature has identified many factors influencing performance budgeting, but more efforts are still needed to structure the factors into some holistic frameworks. There is a consensus that measurement, support for performance, capacity and training, and the presence and content of performance laws contribute positively to the success of performance budgeting, 
but there is little consensus on whether the characteristics of the implementing organization and implementation approach matter.

\section{Review of Research Methodology}

This study also examines what methodologies are used to analyze the practice and impacts of performance budgeting and how these methods evolve over time. We coded articles based on five common methods: case study and interviews, surveys, content analysis, descriptive statistics, and multivariate statistics. A given article may include more than one method. For example, a case study based on interviews or surveys may also contain descriptive and multivariate statistical analysis. In this case, all three methods would be coded for the article. Based on this coding scheme, we found that fourteen out of 61 articles reviewed do not have any formal research method and focus on a general or theoretical discussion of performance budgeting.

Among all the articles, the most frequently used method is descriptive statistics, which are found in 27 articles (44.3\%) (see Table 4). Case studies and interviews, the next most frequently used method, are found in 22 articles (36.1\%). Sixteen articles (26.2\%) use surveys and fourteen articles (23.0\%) use multivariate statistics. Content analysis is employed only four times $(6.6 \%)$. The pattern of methodology usage does not show any clear trend over time, except that descriptive statistical analysis has been used relatively more consistently since 2004, both in the analysis of state performance budgeting reforms (Burns \& Lee, 2004; Jordan \& Hackbart, 2005; Lu et al., 2009; Willoughby, 2004) and in the analysis of federal initiatives (Dull, 2006; Long \& Franklin, 2004; Mullen, 2006). The utilization of other methods has fluctuated more obviously. For example, the use of surveys was at its peak in 2006 but has declined since 
then. Content analysis has been used sporadically, with only four articles over the study period (Franklin, 2002; Frisco \& Stalebrink, 2008; Ho \& Ni, 2005; Lee \& Wang, 2009) . Given the fact that both surveys and content analysis require an extensive time and labor investment, it is understandable that they have not been used regularly.

[Table 4 about here]

In more recent years, there have been more studies using multivariate statistical analyses. In addition to multivariate regression (Franklin, 2002; Ho \& Ni, 2005; Melkers \& Willoughby, 2005), other empirical methodologies, such as cluster analysis, time series regression, and structural equation modeling have also been used (Handley \& Howell-Moroney, 2010; Lee \& Wang, 2009; Lu, 2011). However, statistical modeling is still not a dominant methodology. One of the barriers to statistical analysis is the availability of data. Even though over time, departmental and program budget performance information has become more transparent and publicly available, how performance information is actually used and how the usage differs by agencies, program nature, and leadership structure are still a puzzle. To answer these questions, researchers often need to rely on in-depth interviews, field observations, and documentary research (Courty \& Marschke, 2003; Gueorguieva et al., 2009; Ho, 2011; Kasdin, 2010; Martin $\&$ Singh, 2004). Hence, until there is a more systematic release of program performance and budget data and the process characteristics of the budgetary decision-making process, attempts to conduct any large scale quantitative analysis of performance budgeting practice and impact will remain a challenge, and the field still needs well-designed qualitative studies to provide in-depth insights on how performance information is used in the budgetary process.

\section{Theoretical Frameworks Used}


We also review the theoretical foundations of the past studies. To our surprise, among the 61 studies examined, most (45) do not contain any theoretical framework. They are descriptive in nature, trying to help readers understand how performance budgeting was implemented by a particular government during a certain era. This descriptive focus is perfectly acceptable, especially when new performance reform initiatives are introduced and researchers and readers are trying to find out what really happens before theorizing the causal relationships or implementation hurdles faced by the reforms. However, as the field continues to mature, a more theoretical focus will be necessary.

Among the 16 studies that have incorporated some theoretical discussion or perspectives, we find no clear dominant paradigm that guides the work on performance budgeting. Some studies look at performance budgeting as a budget phenomenon and provide some theoretical discussion of the tool in the context of budget incrementalism and rationalism (Kelly \& Rivenbark, 2008; Pitsvada, \& LoStracco, 2002; Reddick, 2007). Others look at performance budgeting more from an organizational management perspective and examine how the structure and process, organizational nature, and managerial capacity influence the implementation and success of reforms (Gueorguieva et al., 2009; Moynihan, 2006; Sterck, 2007). There are also some who treat performance budgeting as a policy phenomenon and apply implementation theories and other policy evaluative frameworks to evaluate different performance budgeting initiatives (Greitens \& Joaquin, 2010; Grizzle \& Pettijohn, 2002; Long \& Franklin, 2004).

Hence, there is no clear dominant theory of performance budgeting, and the field is still wide open for a more in-depth theoretical examination of the phenomenon. An earlier critique by Yang and Hsieh (2007) about performance measurement studies seems to be equally applicable in the field of performance budgeting: "the literature on government performance measurement 
is largely descriptive and prescriptive, with limited attention to theory building and hypothesis testing" (2007, p. 861). Hence, a stronger focus on the theoretical anchors of performance budgeting will be helpful to advance its future practice and research.

\section{The Limits of Performance Budgeting?}

Finally, any review of the use of performance information as a tool for budgeting would not be complete without discussing its limits and some of the seemingly perpetual concerns. To us, this issue is important because these limits bring to light some of the tricky research topics in the field that are currently understudied. For instance, V.O. Key (1940) raises a fundamental question of budgeting, "On what basis should we budget?" This is linked directly to the fundamental premise of performance budgeting. Should performance information and results be a legitimate basis on which a government should budget? The field seems to suggest compelling arguments for both "yes" and "no". One of the most compelling challenges to the performance movement pertains to the issue of democratic values (Radin, 2006). To many scholars, values such as democracy and public demands should take precedence over program efficiency and effectiveness in budgeting consideration (Shah \& Shen, 2007). At the same time, other scholars in the field argue for the important role of performance information in budgeting, especially as a way to inform decisions. What complicates the question further is the politics surrounding budgeting. Performance information may get noticed because it fits well with the political agenda of politicians at one moment, but may get ignored because it contradicts with their agenda later. As Posner and Fantone (2007, p. 365) delicately put it:

"although too little attention is commonly viewed as undermining previous performance budgeting initiatives, the linkage of performance metrics with the budget and policy 
agendas of particular political actors carries its own risks and challenges as well. Although these risks may, in fact, be an inevitable consequence of a heightened attention to performance information, a risk exists that this could undermine the compelling appeal that performance frameworks and information have for decision makers-namely, their perceived legitimacy as an expert-based approach to capture the consequences of decisions for results.”

Indeed, as one reviewer of this research points out, "performance faces risks both in being irrelevant for budget and policy debates and in being too relevant." While the risk of being irrelevant has been known for a long time, the risk of being too relevant also seems to fly in the face of performance legitimacy, because this risk subjects the integrity of performance budgeting to political maneuvering and gaming. Recent cases in the U.S., such as school superintendents' cheating under the accountability framework established by the No Child Left Behind legislation, or the New York City Police Department's controversial practices of stop and frisk under the tight grip of the COMPSTAT performance system, are some examples showing that performance information can be misused if it becomes "too relevant" in the policymaking and resource allocation process. As the reviewer vividly describes, no one will willingly load a gun that is pointed at their head. As such, the question about the legitimate usage of performance information in budgeting still begs more careful consideration. Future research may analyze further under what political and organizational conditions performance information can be used legitimately and relevantly in budgeting without compromising its integrity.

A related challenge to performance budgeting at the operational level is what managers and budgeters should do with performance information, assuming good political support and excellent performance information quality. More specifically, a repeated question either clearly 
stated or implied in performance budgeting is whether the government should cut a program's budget in light of high program performance, assuming they can do better with less, or increase its budget in light of low performance, assuming that more resource availability may improve performance. Prior studies as well as the practice in this field do not have a definite answer to this question. The intractability of operational consistency also puts a limit on the extent to which there is any direct relationship between performance and budgeting. Clearly, the relationship cannot be linear and mechanical. Then, what kind of relationship should it be? The dialogue theory suggested by Moynihan (2006) seems to confirm that the relationship is ad hoc and ambiguous. At best it could be described as "it depends". That probably explains the subtle change in the literature from "performance-based budgeting" to "performance-informed budgeting." However, the literature has not done enough to attempt to delineate the ad hoc relationship. Future research may explore further questions such as "on what it depends," "how it works," or "under what circumstances a positive or negative relationship between performance and budgeting may improve performance".

The third limit to performance budgeting is that we do not know how human behavior responds to financial incentives, particularly when the relevant dimensions of performance may be difficult to capture. Some of the surveyed articles allude to the possible adaptation and unintended consequences of increased performance attention, especially when the budget is linked with performance. For instance, Courty and Marschke (2003, p. 22) in their study of performance funding in federal job training program find that "states' modifications to the scheme's construction produced over time highly individualized performance funding schemes that likely varied in their effectiveness." This shows that behaviors may change in response to performance measurement. As behaviors may not change consistently across groups, or they may 
change in any unexpected ways, there are concerns about incentive effectiveness and unintended consequences. Additionally, the use of incentives is impaired by the inability to capture all of the relevant dimensions of programs that have outputs and outcomes that are difficult to measure. This is why Radin has claimed that "one-size-fits-all" performance measurement can lead to "perverse responses that do not lead to increased attention to performance" $(2009, \mathrm{p} .130)$. How to address these incentive design issues is a fundamental challenge for performance budgeting and may explain why the use of financial (dis)incentives in budget laws is rare (Lu et al., 2009). Future studies may therefore explore further how budget allocation should (or should not) be used as an incentive for performance in light of these complexities.

\section{Conclusion and Suggestions for Future Research}

Based on our review of 61 journals published in 2002-2011 that are related to performance budgeting or performance reform issues in the budgetary process, we analyze the trends of primary research questions, the major methodologies used, and the key factors that impacted the success of performance budgeting and the integration of performance information into the budgetary process. Our findings show that significant progress has been made in the field, such as the diversification of research methods over time, and the development of a wide array of factors that seem to be the key to the implementation success of performance budgeting. However, we are also not satisfied with the current status of the field. Particularly, we propose that future studies should utilize better research design or methodologies to control for different intervening factors over time to establish causality. Also, many studies lack explicit theoretical frameworks to guide the qualitative and quantitative analyses. As a result, the field still faces significant limitations in producing generalizable and actionable knowledge for practitioners. 
Having identified 27 types of factors, an interesting question is whether we have enough factors to understand the dynamics of implementing performance budgeting. Alternatively, do we already have too many? A reasonable basis of comparison could be the policy implementation literature, since in essence those studies are about implementing the policy of performance budgeting. In their seminal work on policy implementation, Mazmanian and Sabatier's (1989) model includes three broad categories of manipulable variables that help to explain implementation success:

1. Tractability of the problem being addressed by the statute (i.e., availability of technology to solve the problem; diversity and size of target group; the extent of behavioral change sought);

2. Ability of the statute to structure implementation (i.e., clear and consistent objectives, sound causal theory; financial resources; hierarchical integration with and among implementing institutions; decision-rules for implementers; selection of implementing officials, formal access to outsiders);

3. Non-statutory variables that affect implementation (i.e., socioeconomic conditions; media attention; public support; support from sovereigns; commitment and leadership skill of implementing officials; and the disposition and resources of constituency groups).

If we apply their model to understand the implementation of performance budgeting, we conclude that we have not studied enough factors. For instance, in relation to the legislature using performance information in budgeting, the literature has no clear response on the disposition and resources of their constituency groups, such as the role of citizens and policy lobbyists. In addition, new governance structures, such as multi-actor networks, demand new perspectives (factors) on performance budgeting. Probably, a more important lesson from this 
comparison is that the field of performance budgeting needs to organize the factors into a framework, just as the policy implementation field has done. As the field progresses, the need to organize our understanding in a systematic way will be as important as identifying new factors.

One benefit of building frameworks is that it helps us uncover the inter-connectedness between implementation strategies, the larger institutional contexts, and the micro-behavioral factors. "Success" is a normative concept and is tied directly to the original intention of a reform, but the goals and strategies of the reform are contextually bounded and driven by many political, economic, social, and organizational considerations of policymakers (Radin, 2006). Also, leadership styles and strategies matter. For example, agencies may try to set conservative goals to guarantee success, but they can be pushed by the executive leadership or policymakers to be more aggressive or risk-taking in outcome goal setting (Ho, 2007). Demand from different constituencies and stakeholders may also lead to conflicting and sometimes unachievable goals and targets (Radin, 2000). All these may lead to implementation difficulties, failures, and gaming behaviors (Bevan and Hood, 2006; Hood, 2006). As a result, future studies need to focus more on the relationship between the intentionality, system design, implementation strategies, and leadership of performance budgeting (Ho and Im, 2014). Also, the study of performance budgeting needs to go deeper into the decision-making process, going beyond the departmental analysis to the analysis of budget funds, programs, and even program activities. By doing so, the contextual constraints on budgeting as well as the role of performance information in budgeting could be explained better. In this endeavor, other fields, such as organizational theories, policy implementation theories, dialogue theory, and institutional theories, may be helpful. 
In addition, we need to understand further the limitations of performance budgeting, because they can help us form ultimate and realistic expectations of the success of performance budgeting. For example, as we asked before, should we increase or decrease funding in light of performance information, assuming enough political support and reasonable performance information quality? The field poses this question as a dilemma, but it does not seem to recognize this as a researchable question. Although the lack of empirical data may limit this research endeavor, and budgetary behaviors are hard to observe in the short term, we suggest that in-depth case studies may be a good starting point, while more departmental, program, or activity-level budgeting and performance data should be collected by researchers at the federal, state and local levels to tease out the extent and implications of a positive or negative relationship between performance and resource allocation.

As researchers include more variables and more complicated frameworks, there is likely to be a further bifurcation in the methods that are used to study performance budgeting. On the one hand, there is a need for more in-depth case and qualitative studies to analyze those variables and factors that are important but difficult to quantify. On the other hand, there is also a need for more advanced quantitative analysis. Movement toward more sophisticated models like structural equation modeling has the potential to capture difficult-to-measure qualitative variables and to model these variables in simultaneous ways that are much more like the realworld policy environments encountered by budget makers and organizational leaders. The research challenge is to bridge the gap between academic public administration and public administration in practice (Waldo, 1956). For performance budgeting this requires a diversity and continued refinement of research methods. 
Importantly, with the changing governance contexts faced by many countries, such as growing deficits and looming unfunded liabilities in many developed economies, the rising importance of multi-sectoral governance in service delivery, rising partisanship in the legislature, and growing distrust of the public sector, the focus of many performance budgeting studies seems to be too narrow (Van Dooren, De Caluwe \& Lonti, 2012). It only examines how the tool may impact the appropriation process without thinking about how the changing governance contexts may and should impact the design and implementation of the tool, and how the tool in return may help address the governance challenges faced by policymakers. As the practice of performance budgeting begins to take root in more countries, including many non-western developing countries, we anticipate that the practice will become even more institutionally diffuse and diverse. Therefore, it is important to have more theoretical development that is contingency-based and institutionally sensitive so that researchers and practitioners can understand how culture, organizational norms, political system, and fiscal constraints may impact reform goals, strategies, and reform results (Ho and Im, 2014). Diverse methods, theories, and contexts are likely necessary to further our understanding of how performance can inform budgeting.

Given the above understanding, we conclude by suggesting the following lessons learned from the past studies and what future studies may explore further.

1. Start the research with a clearer definition of the dependent variable of study and further explore the impact of performance budgeting in all phases of the budgeting process, in particular the fiscal and non-fiscal impact of performance information and analysis on budget preparation and budget execution; 
2. Refine the theoretical focus of performance budgeting, identify the key variables of importance rather than proposing more variables in the analysis, and examine the interrelationships of variables in the framework, especially the relationship between reform goals, reform strategies, politics, administrative capacity, and leadership;

3. Pay closer attention to the macro contextual factors such as the political institution, culture, and social norms and their impact on behaviors in performance budgeting; this consideration of contingency-based and institutionally sensitive approach to research is particularly important for comparative research, domestic and international;

4. Examine the practice and impact of performance budgeting at the program or activity level, not just at the organizational or agency level;

5. Study performance budgeting under new governance schemes, such as governing by networks, private-public partnerships, and citizen engagement, since the traditional organizational focus of performance budgeting is not broad enough to embrace these governance challenges;

6. Continue to embrace pluralism in methods. It is appropriate to use different types of methods contingent upon the availability of data and on context, and there is a need for collection of both qualitative and quantitative data.

7. Further explore the limits and boundaries of performance budgeting, and the possible unintended negative consequences of performance budgeting on organizational behaviors and policy outcomes.

In the current fiscal and economic environment, many countries are challenged to do more with less and are under greater global competitive pressure to deliver effective public 
services. As a result, public service performance, policy results, and budgeting have become inseparable. It is in this context that we believe performance budgeting will continue to play an important role in the practice of public budgeting and governance. 


\section{Endnotes}

1. The 14 journals were Public Budgeting and Finance, Journal of Public Policy Analysis and Management, Journal of Public Administration Research and Theory, Governance, Public Administration Review, Public Administration, American Review of Public Administration, Public Performance and Management Review, International Review of Administrative Science, Journal of Public Budgeting, Accounting, and Financial Management, Review of Public Personnel Administration, Public Management Review, Administration and Society, and International Public Management Journal. 
Appendix

[Appendix Table Here] 


\section{References}

Andrews, M. (2004). Authority, acceptance, ability and performance-based budgeting reforms. The International Journal of Public Sector Management, 17(4), 332-44.

Bevan, G. and Hood, C. (2006). What's measured is what matters: Targets and gaming in the English public health care system. Public Administration, 84(3), 517-538.

Behn, R.D. (2002). The psychological barriers to performance management. Public Performance \& Management Review, 26(1), 5-25.

Behn, R.D. (2003). Why measure performance? Different purposes require different measures. Public Administration Review, 63(5), 586-606.

Bourdeaux, C. (2008). Integrating performance information into legislative budget processes. Public Performance \& Management Review, 31(4), 547-569.

Breul, J. (2007). GPRA — a foundation for performance budgeting. Public Performance \& Management Review, 30(3), 312-331.

Burns, R.C., \& Lee, R.D. (2004). The ups and downs of state budget process reform: Experience of three decades. Public Budgeting \& Finance, 24(3), 1-19.

Chi, K.S. (2008). Four strategies to transform state governance. Washington, DC: IBM Center for the Business of Government.

Christensen, T. (2012). Global ideas and modern public sector reforms: A theoretical elaboration and empirical discussion of a neoinstitutional theory. American Review of Public Administration, 42(6), 635-653.

Curristine, T. (2005). Performance information in the budget process: Results of the OECD 2005 questionnaire. OECD Journal 5(2), 87-131. 
Courty, P., \& Marschke, G. (2003). Performance funding in federal agencies: A case study of a federal job training program. Public Budgeting \& Finance, 23(3), 22-48.

Dull, M. (2006). Why PART? The institutional politics of presidential budget reform. Journal of Public Administration Research and Theory, 16(2), 187-215.

Franklin, A.L. (2002). An examination of the impact of budget reform on Arizona and Oklahoma appropriations. Public Budgeting \& Finance, 22(3), 26-45.

Frisco, V., \& Stalebrink, O.J. (2008). Congressional use of the program assessment rating tool. Public Budgeting \& Finance, 28(2), 1-19.

Gilmour, J. B., and Lewis, D. E. (2005). Assessing performance budgeting at OMB: The influence of politics, performance, and program size. Journal of Public Administration Research and Theory, 16(2), 169-186.

Gilmour, J. B., and Lewis, D. E. (2006). Does performance budgeting work? An examination of the Office of Management and Budget's PART scores. Public Administration Review, 66(5), 742-752.

Greitens, T. J. \& Joaquin, M.E. (2010). Policy typology and performance measurement: Results from the Program Assessment Rating Tool (PART). Public Performance \& Management, Review, 35(3), 489-508.

Grizzle, G. A., \& Pettijohn, C. D. (2002). Implementing performance-based program budgeting: A system-dynamics perspective. Public Administration Review, 62(1), 51-62.

Gueorguieva, V., Accius, J., Apaza, C., Bennett, L., Brownley, C., Cronin, S. \& Preechyanud, P. (2009). The Program Assessment Rating Tool and the Government Performance and Results Act: Evaluating conflicts and disconnections. American Review of Public Administration, 39(3), 225-245. 
Handley, D.M., \& Howell-Moroney, M. (2010). Ordering stakeholder relationships and citizen participation: evidence from the Community Development Block Grant program. Public Administration Review, 70(4), 601-609.

Ho, A.T. (2007). The governance challenges of the Government Performance and Results Act: A case study of the Substance Abuse and Mental Health Administration. Public Performance and Management Review, 30(1), 35-46.

Ho, A. T. (2011). PBB in American Local Governments: Not Just for Budgeting, and More Than a Management Tool. Public Administration Review, 71(3), 391-401.

Ho, A.T., \& Coates, P. (2002). Citizen participation: Legitimizing performance measurement as a decision tool. Government Finance Review, 18(2), 8-10.

Ho, A.T., \& Coates, P. (2004). Citizen-initiated performance assessment - the initial Iowa experience. Public Performance and Management Review, 27(3), 29-50.

Ho, A. T., \& Im, T. (forthcoming). Challenges in building an effective and competitive government in developing countries: An institutional perspective. American Review of Public Administration. http://arp.sagepub.com/content/early/2013/09/16/ 0275074013501856.full.pdf.

Hood, C. (2006). Gaming in Targetworld: Approach to managing British public services. Public Administration Review, 66(4), 515-521.

Ho, A.T., \& Ni, A. (2005). Have cities shifted to outcome-oriented performance reporting?-A content analysis of city budgets. Public Budgeting and Finance, 25(2), 61-83.

Hou, Y, Lunsford, R.S., Sides, K.C., \& Jones, K.A. (2011). State performance-based budgeting in boom and bust years: An analytical framework and survey of the states. Public Administration Review, 71(3), 370-388. 
Jordan, M.M., \& Hackbart, M. (2005). The goals and implementation success ofstate performance-based budgeting. Journal of Public Budgeting, Accounting \& Financial Management, 17(4), 471-487.

Joyce, P.G. (1993). Using performance measures for federal budgeting: Proposals and prospects. Public Budgeting \& Finance, 13(4), 3-17.

Joyce, P. G. (2003). Linking performance and budgeting: Opportunities in the federal budget process. Arlington, VA: IBM Center for the Business of Government.

Kamensky, J.M. (2012). Is the performance glass half empty or half full? Public Administration Review, 72(4), 603-604.

Kasdin, S. (2010). Reinventing reforms: How to improve program management using performance measures. Really. Public Budgeting \& Finance, 30(3), 51-78.

Kasymova, J. T., \& Schachter, H. L. (2014). Bringing Participatory Tools to a Different Level. Public Performance \& Management Review, 37(3), 441-464.

Kelly, J. M. \& Rivenbark, W. C. (2008). Budget theory in local government: The processoutcome conundrum. Journal of Public Budgeting, Accounting \& Financial Management, 20(4), 457-481.

Klase, K. A., \& Dougherty, M. J. (2008). The impact of performance budgeting on state budget outcomes. Journal of Public Budgeting, Accounting and Financial Management, 20(3), 277-298.

Key, V. O. (1940). The lack of a budgetary theory. American Political Science Review, 34(6), 1137-1144.

Kim, S. \& Schacter, H.L. (2013). Citizen Participation in the Budget Process and Local Government Accountability. Public Performance \& Management Review, 36(4), 456-471. 
Lee, J., \& Wang, X. (2009). Assessing the impact of performance-based budgeting: A comparative analysis across the United States, Taiwan, and China. Public Administration Review, 69, S60-S66.

Lindblom, C.E. (1979). Usable knowledge: Social science and social problem solving: Yale University Press.

Long, E., \& Franklin, A.L. (2004). The paradox of implementing the Government Performance and Results Act: Top-down direction for bottom-up implementation. Public Administration Review, 64(3), 309-319.

Lu, Y. (2007). Performance budgeting: The perspective of state agencies. Public Budgeting \& Finance, 27(4), 1-17.

Lu, Y. (2008). Managing the design of performance measures: the role of agencies. Public Performance \& Management Review, 32(1), 3-20.

Lu, Y. (2011). Individual engagement to collective participation: The dynamics of participation Pattern in Performance Budgeting. Public Budgeting \& Finance, 31(2), 79-98.

Lu, Y., and Willoughby, K. (2012). Performance budgeting in the states: An assessment. The Business of Government Magazine, (Fall/Winter 2012), 71-75.

Lu, Y, Willoughby, K., \& Arnett, S. (2009). Legislating results: Examining the legal foundations of PBB systems in the states. Public Performance \& Management Review, 33(2), 266287.

March, J. G., \& Olsen, J. P. (1989). Rediscovering institutions. New York: Free Press.

Martin, L.L., \& Singh, K.K. (2004). Using government performance management data to identify new business opportunities: Examples from government services outsourcing in the United States. International Review of Administrative Sciences, 70(1), 65-76. 
Mazmanian, D.A., \& Sabatier, P.A. (1989). Implementation and public policy. Lanham, MD: University Press of America.

Melkers, J. E. \& Willoughby, K. G. (2001). Budgeters' views of state performance-budgeting systems: Distinctions across branches. Public Administration Review, 61(1), 54-64.

Melkers, J.E., \& Willoughby, K.G. (2005). Models of performance-measurement use in local governments: Understanding budgeting, communication, and lasting effects. Public Administration Review, 65(2), 180-190.

Moynihan, D.P. (2006). What do we talk about when we talk about performance? Dialogue theory and performance budgeting. Journal of Public Administration Research and Theory, 16(2), 151-168.

Moynihan, D.P., \& Lavertu, S. (2012). Does involvement in performance management routines encourage performance information use? Evaluating GPRA and PART. Public Administration Review, 72(4), 592-602.

Mullen, P. R. (2006). Performance-Based Budgeting: The Contribution of the Program Assessment Rating Tool. Public Budgeting \& Finance, 26(4), 79-88.

National Performance Management Advisory Commission (NPMAC). (2010). A Performance Management Framework: From Measurement and Reporting to Management and Improving for State and Local Government. Available at www.nasbo.org/sites/default/files/APerformanceManagementFramework.pdf, accessed April 10, 2014.

Newcomer, K. (2007). How does program performance assessment affect program management in the federal government? Public Performance \& Management Review, 30(3), 332-350. 
Organization for Economic Co-operation and Development (OECD). (2007). Performance Budgeting in OECD Countries. Paris.

O’Toole, L. J. (1986). Policy recommendations for multi-actor implementation: An assessment of the field. Journal of Public Policy, 6(2), 181-210.

O'Toole, L.J., \& Meier, K. J. (2010). In defense of bureaucracy. Public Management Review, 12(3), 341-361.

Perry, J.L. (2012). How can we improve our science to generate more usable knowledge for public professionals? Public Administration Review, 72(4), 479-482

Peters, B. G. (2012). Institutional theory in political science: The new institutionalism (3rd ed.). London: Continuum.

Poister, T.H., \& Streib, G. (1999). Performance measurement in municipal government: assessing the state of the practice. Public Administration Review, 59(4), 325-335.

Posner, P.L., \& Fantone, D.M. (2007). Assessing federal program performance: Observations on the U.S. Office of Management and Budget's Program Assessment Rating Tool and its use in the budget process. Public Performance \& Management Review, 30(3), 351-368.

Pitsvada, B., \& LoStracco, F. (2002). Performance budgeting--the next budgetary answer. But what is the question? Journal of Public Budgeting, Accounting \& Financial Management, 14(1), 53-73.

Reddick, C. G. (2007).State resource allocation and budget formats: Towards a hybrid model. Journal of Public Budgeting, Accounting \& Financial Management, 19(2), 221-244.

Radin, B. A. (2000). The Government Performance and Results Act and the tradition of federal management reform: Square pegs in round holes? Journal of Public Administration Research and Theory, 10(1), 111-135. 
Radin, B.A. (2006). Challenging the performance movement: Accountability, complexity and democratic values. Washington, DC: Georgetown University Press.

Radin, B.A. (2011). Federalist no. 71: Can the federal government be held accountable for performance? Public Administration Review, 71, S128-S134.

Rivenbark, W. C. (2006). Evolutionary theory of routine: Its role in results-based management. Journal of Public Budgeting, Accounting \& Financial Management, 18(2), 223-240.

Rivenbark, W. C., \& Kelly, J. M. (2006). Performance Budgeting in Municipal Government. Public Performance \& Management Review, 30(1), 35-46.

Shah, A., \& Shen, C. (2007). A primer on performance budgeting. Available at siteresources.worldbank.org/PSGLP/Resources/ShahandShenpaper.pdf, accessed August $31,2012$.

Stalebrink, OJ., \& Frisco, V. (2011). PART in retrospect: An examination of legislators' attitudes toward PART. Public Budgeting \& Finance, 31(2), 1-21.

Sterck, M. (2007). The impact of performance budgeting on the role of the legislature: a fourcountry study. International Review of Administrative Sciences, 73(2), 189-203.

U.S. General Accounting Office (GAO). (2003, April). Performance Budgeting: Current Developments and Future Prospects. GAO-03-595T.

U.S. Government Accountability Office (GAO). (2005, September). Managing for results: Enhancing angecy use of performance information for management decision making. GAO-05-927.

Van Dooren, W., De Caluwe, C., \& Lonti, Z. (2012). How to Measure Public Administration Performance. Public Performance \& Management Review, 35(3), 489-508 
Wescott, C. G., \& Jones, L. R. (2007). Managing for results and performance in Asia: Assessing reform initiatives in the public sector. International Public Management Review, 8(1), 56-102.

Wescott, C., Bowornwathana, B., \& Jones, L. (Eds.). (2009). The many faces of public management reform in the Asia-Pacific region. Oxford, UK: Emerald Group Publishing.

Wichowsky, A. \& Moynihan, D. P. (2008). Measuring how administration shapes citizenship: A policy feedback perspective on performance management. Public Administration Review, 71, S128-S134.

Willoughby, K.G. (2004). Performance measurement and budget balancing: State government perspective. Public Budgeting \& Finance, 24(2), 21-39.

Willoughby, K. G., and Melkers, J. E. (2000). Implementing PBB: Conflicting views of success. Public Budgeting \& Finance, 20(1), 105-120.

Yang, K., \& Hsieh, J.Y. (2007). Managerial effectiveness of government performance measurement: Testing a middle-range model. Public Administration Review, 67(5), 861879. 
Dr. Elaine Yi Lu is an Associate Professor in the Department of Public Management at John Jay College City University of New York (CUNY). Her primary research interests are performance budgeting, performance management and financial management. She could be reached at ylu@jjay.cuny.edu.

Dr. Zachary Mohr is an Assistant Professor in the Department of Political Science and Public Administration at the University of North Carolina Charlotte. His primary research interests are cost accounting, financial management, and their intersection with public management topics like performance measurement and management. He can be reached at zmohr@uncc.edu.

Alfred Ho is an Associate Professor at the School of Public Affairs and Administration, University of Kansas. His primary research focuses on performance budgeting, citizen engagement, and e-government. He can be reached at alfredho@ku.edu. 